\title{
A FOGYASZTÓ ÉS A MÁRKA KÖZÖTTI VISZONY ÚJ DIMENZIÓI
}

Jelen tanulmány a széles körben vitatott fogyasztó-márka viszonyt és a szeretetmárkák koncepcióját mutatja be, nemzetközi kitekintés mellett, a szerzők primer kutatási eredményeire, következtetéseire koncentrálva. A szerzők a márkaviszony-elmélet (brand relationship theory) keretein belül bemutatják, hogyan értelmezhető a fogyasztó és a márka közötti viszony az interperszonális kapcsolatok analógiájaként. A márkaviszony-minőség elmélete (brand relationship quality theory) alapján ismertetik, hogy a fogyasztó és a márka közötti viszony hogyan jelenhet meg különböző minőségi szinteken. A szerzők fókuszcsoportos kutatást végeztek négy csoporttal, amely során az egyén és a márka közötti kapcsolat sajátosságait kívánták feltárni. Az eredmények a márkák felé irányuló érzelmek sokszínűségét hangsúlyozzák. A vizsgált márkáknál a márkahűség egyfajta belső elköteleződésen alapul, mely olyan érzelmi ragaszkodást jelent, ami miatt nem akarja „elárulni” a márkát az egyén egy konkurens márkára való váltással.

\section{Kulcsszavak: márkaszeretet, márkaviszony-elmélet, márkaviszony-minőség, lojalitás}

$\mathrm{N}_{k}^{a}$ apjainkban a vásárlás célja az alapvető szükségletek kielégítésén túl, az önmegvalósítás és az élmények gyüjtése, illetve azoknak a szimbolikus hasznoknak a megszerzése lett, amelyeket a márkák közvetítenek. Megfigyelhető az a jelenség, hogy bizonyos márkák hatalmas rajongótáborral rendelkeznek, és ezek a márkák képesek olyan erős és mély érzelmeket kiváltani a fogyasztókból, amelyeket korábban csak az interperszonális kapcsolatok szintjén tudtunk elképzelni. A fogyasztók márkák iránti lojalitása ebben az esetben túlmutat a termék funkcionális hasznosságán alapuló márkahüségen.

Tanulmányunkban a márkaszeretet koncepcióját vizsgáljuk, mellyel ugyan elméleti és gyakorlati szinten egyaránt sokat foglalkoznak napjainkban, de még mindig hiányzik a kellően letisztult keretrendszer, ezért érdemesnek tartjuk e területet a szakirodalmi áttekintés mellett feltáró kutatással is vizsgálni. Kutatásunk célja mélyrehatóan vizsgálni a fogyasztó és az általa szeretett márka közötti viszony sajátosságait. Választ kívánunk adni arra a kérdésre, hogy egyáltalán beazonosítható-e érzelmi kötődés a márka és fogyasztója között, és amennyiben igen, akkor ez miként jelenik meg viselkedés, attitüd és vélemény szintjén.

A fogyasztó és a márka közötti kapcsolat feltárása során először rövid szakirodalmi áttekintést végzünk a márkák szimbolikus tartalmára, valamint a lojalitás komplex jellegére vonatkozóan. Ezt követően a márkaszeretet koncepciójával kapcsolatos elméleti megközelítéseket ismertetjük, különös tekintettel a márkaviszony-elméletre és a márkaviszony-minőség elméletére. Végül bemutatjuk fókuszcsoportos kutatásunk főbb eredményeit, illetve következtetéseinket és a jövőre vonatkozó megállapításainkat.

\section{A márkaszimbolizmus}

Az ,azok vagyunk, amiket birtoklunk” kijelentés (Belk, 1988), a fogyasztói magatartás - ezen belül is a szimbo- likus fogyasztás vizsgálatának - egyik alapvető premiszszája. A szimbolikus fogyasztás jelenségének leírását egészen Thorsten Veblenig (1925/2006) - sőt Adam Smith-ig (1759/1975) - visszavezethetjük, hiszen már e korai gondolkodók is vizsgálták az egyén és az általa birtokolt javak közötti viszony szimbolikus jellegét. A modern marketingben Levy (1959) tanulmánya tekinthető alapozó münek, amelyben rávilágított arra, hogy a fogyasztók nem csak a funkcionális hasznokért vásárolják meg a termékeket, hanem a hozzájuk társított jelentéstartalmak miatt is. A hazai szakirodalomban Törőcsik (2000) a következőképpen fogalmazta meg a szimbolikus fogyasztás lényegét: „Egyrészt olyan termékek vásárlását, majd fogyasztását jelenti, amelyek szükségességét nehéz megmagyarázni, nem logikus, hogy megvettük, nem következik élethelyzetünkböl, esetleg korábbi vásárlói, fogyasztói magatartásunkból. Másrészt olyan márkák vásárlását majd fogyasztását, amelyekkel, illetve amelyek üzeneteivel azonosulni szeretnénk, kifejezve valami többletet magunkból, illetve biztositva magunknak valamiféle érzelmi többletet" (Töröcsik 2000, 47. o.).

A márkaszemélyiség - mint a márkaimázs antropomorfizált része - fontos tényezőként jelenik meg a márkák szimbolikus tartalmában, és egy alapvető kapocs a márkahüség kialakulásában, illetve annak fennmaradásában. Aaker (1997) szerint a márkaszemélyiség a márka emberi tulajdonságokkal való felruházását, és ezeknek a tulajdonságoknak az összességét jelenti. A márkaszemélyiség által a fogyasztó könnyebben képes az emberi kapcsolatokhoz hasonló viszonyt kialakítani a márkával. Sőt akár azonosulni tud vele.

Az egyén identitása és a márka által sugallt kép közötti egyezőséget énkép-illeszkedésnek (self-image congruency) nevezzük (Sirgy, 1982). A szimbolikus fogyasztási döntést gyakran befolyásolja az, hogy mennyiben illeszkedik a termék imázsa, avagy a márkaszemélyiség a fogyasztó énképéhez (Gyulavári - Malota, 2014; Kressman et al., 2006; Grzeskowiak - Sirgy, 2007). Aaker (1997) 
szerint minél nagyobb az egyezés a márkaszemélyiség és az egyén aktuális vagy ideális énképe között, annál jobb helyen fog szerepelni a márka a fogyasztó preferenciarendszerében. Az énkép fogyasztásra gyakorolt hatása mögött két okot feltételezhetünk: az önbecsülést (self-esteem) és az önkonzisztenciára (self-consistency) való törekvést. Az önbecsülés miatt az egyén olyan élményeket vagy termékeket keres, amelyek erősítik az énképét, javítják megítélését. Az önkonzisztencia pedig azt jelenti, hogy az egyén próbál úgy cselekedni, hogy az egyezzen a saját magáról alkotott képpel (Sirgy, 1982). Ez a kettősség a szimbolikus fogyasztás külső és belső dimenziókra való osztásában is megjelenik, melynek értelmében a külső szimbolikus fogyasztás a mások felé irányuló önkifejezést szolgálja, míg a belső (önmegnyugtató) szimbolikus fogyasztás során a fogyasztó saját maga számára nyújt kellemes érzést például megnyugvást, jutalmat, örömöt (Törőcsik, 2009). Tanulmányunkban ez utóbbi jelenséget, vagyis az önmegnyugtató fogyasztást vizsgáljuk részletesebben.

\section{A márkalojalitás érzelmi oldala}

A márkához társított szimbolikus elemek, alapjaiban határozzák meg a márkaválasztást, ebből kifolyólag közvetlenül hatnak a márkahűségre. Az emocionális tényezők kutatása azonban egy komplex megközelítési módot igényel, ugyanis több pszichológiai tényező együttesen alakítja, formálja a márkához való hűséget. Ebből adódóan a lojalitást is érdemes több aspektusból megvizsgálni.

A lojalitás egyrészt értelmezhető racionális viselkedésként is (pl.: törzsvásárlói árelőnyért, kockázatcsökkentési szándékból), másrészt a szakirodalomban ismert a lojalitás érzelmi oldalának vizsgálata is (Bandyopadhyay - Martell, 2007).

A lojalitás mögött általában az elégedettséget szokás feltételezni. Egy elégedett vásárló azonban nem feltétlenül lojális is. Az elégedettség gyakran csak viselkedéses lojalitáshoz (azaz egyszerü újravásárláshoz) vezet, a komplex vevői lojalitás azonban egy magasabb szintet jelent, amelyröl akkor beszélünk, ha az egyén pozitív attitüddel rendelkezik a márkával szemben, illetve ha elköteleződik egy márka iránt (Prónay, 2011). Oliver (1999) elméletében a fogyasztó először kognitív értelemben lesz lojális, majd érzelmi, később konatív értelemben, végül aktív cselekedetei által válik hüségessé. A márkahüség kognitív fázisában a fogyasztó a termék mérhető paraméterei, a márkaattribútumok miatt kedveli a márkát. A fogyasztó elégedett a márkával, de ekkor még nem egy erös, mélyen megalapozott hüségröl van szó. Amennyiben a fogyasztó elégedettsége mélyebb szintre kerül, és érzelmek is megjelennek a márka iránt, akkor beszélhetünk érzelmi lojalitásról - vagy más szerzők (Uncles - Dowling - Hammond, 2003) megfogalmazásában attitüdinális lojalitásról. Amellett, hogy a fogyasztó a márkát folyamatosan használja, elégedett vele, még örömet is okoz neki. Ez egy erősebb kötődés már a márka iránt, de még megingatható a fogyasztó hűsége ezen a szinten. A konatív lojalitás egy még mélyebb kötődést jelent, amikor a fogyasztó elkötelezett a márka iránt. A sorozatosan megismételt pozitív érzelmek és pozitív visszajelzés miatt a fogyasztó már azért veszi meg a márkát, mert szorosan kötődik hozzá. A lojalitás utolsó szintje a cselekvő lojalitás, melynek legfőbb jellemzője, hogy a fogyasztó komoly erőfeszítéseket is hajlandó megtenni azért, hogy a márkát továbbra is megvásárolja, és csak abban az esetben vásárol másik márkát, ha nem érhető el az általa kedvelt termék (Oliver, 1999). Töröcsik (2009) ezt az erős érzelmi érintettséggel jellemzett fogyasztó-márka viszonyt ,igazi” márkahűségnek nevezi, szemben a „kvázi” márkahűséggel, amire gyenge érzelmi érintettség a jellemző.

Tanulmányunkban a bemutatott Oliver-féle (1999) lojalitásszintek közül a konatív és a cselekvő lojalitás vizsgálata kap nagyobb szerepet, ugyanis a lojalitás e két típusánál beszélhetünk mélyen megalapozott hüségről és elköteleződésről, e két esetben nehezebben ingatható meg a fogyasztó hüsége a márka iránt.

\section{A márkához való érzelmi kötődés koncepciói}

A márkához való érzelmi kötődés jelenségét Fournier (1998) a márkaviszony-elmélet (brand relationship theory) keretein belül tárgyalja. A márkaviszony-elmélet azt a jelenséget mutatja be, amikor a fogyasztó úgy tekint a márkára, mintha az egy személy lenne, mellyel a vásárlás és birtoklás során kapcsolatba kerül. Aaker (1997) és Aggarwal (2004) kutatásaikban kimutatták, hogy annak a hátterében, hogy a fogyasztó személyként tekint a márkára, részben az áll, hogy az egyének az élet számos területén különböző személyiségjegyeket társítanak egyegy tárgyhoz, így a fogyasztók gyakran úgy gondolják a tárgyaknak, a termékeknek, illetve a márkáknak lelkük van. A fogyasztónak valamilyen lelki közelséget kell éreznie ahhoz, hogy érzelmek alakuljanak ki benne a márka iránt (Albert - Merunka, 2013). Ahhoz, hogy a márkákhoz való ilyen érzelmi kötődés kialakuljon szükségesek a márkához társított szimbolikus jegyek. Aggarwal (2004) szerint a márka és a fogyasztó közötti viszony folyamatos, ismétlődő interakciókon alapszik. Ezek a kölcsönhatások hasonlóságokat mutatnak az interperszonális kapcsolatokban jellemző érzelmekkel, úgymint szeretet, intimitás, ragaszkodás és elkötelezettség.

Albert és Merunka (2013) kutatási eredményei azt mutatják, hogy a szeretet létező jelenség a fogyasztás területén, azaz valóban lehet ,szeretni” egy márkát. A Saatchi \& Saatchi ügynökség vezetője, Kevin Roberts (2004) vezette be a gyakorlatban azóta is elöszeretettel használt szeretetmárka (lovemarks) megnevezést, a márkákhoz való erős érzelmi kötődés megragadására. Roberts (2004) ,értelmen túli lojalitásként” határozza meg a fogalom lényegét. A márkaszeretet vizsgálata során Batra és szerzőtársai (2012) arra a következtetésre jutottak, hogy a márkaszeretet egyszerre több kondíció meglétét jelenti, amelyek különbözö viselkedésmódok és érzelmek lehetnek. A szerzők nyolc kulcstényezőt állapítottak meg, amelyek szerepet játszanak a márkaszeretet kialakulásában. Ez a nyolc feltétel: a magas minőség (1), a márkával való azonosulás (2), a szenvedély által vezérelt viselkedés (3), 
a fogyasztók pozitív érzelmi kötődése a márkához (4), a hosszú távú kapcsolat megléte - amely arra utal, hogy a márkát már régóta használja a fogyasztó (5), az aggodalom a márkától való elválasztás miatt (6), a pozitív attitűd a márka iránt (7), illetve az erős lojalitás (8). Az 1. ábra szemlélteti az imént felsorolt faktorokat.

\section{A márkaszeretet faktorai}

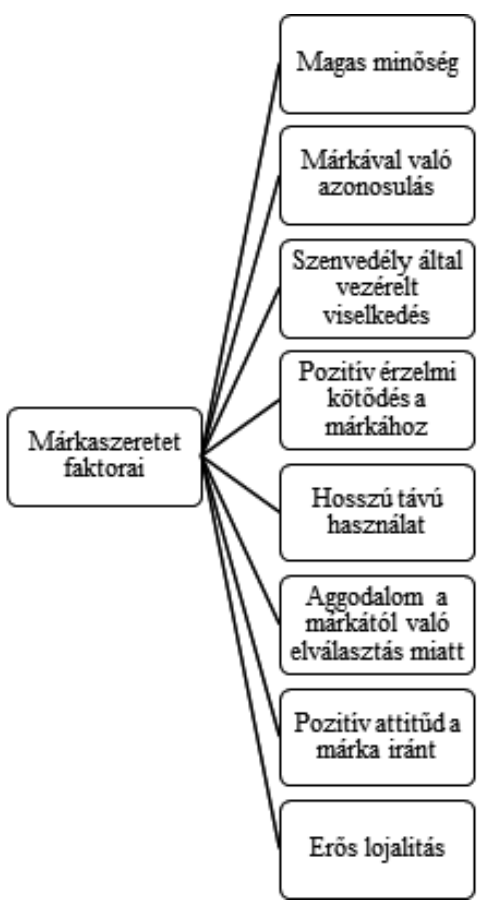

Forrás: Batra et al. (2012)

Fournier (1998) szerint a személyes kapcsolatok négy fontos kritériuma szükséges ahhoz, hogy a márka és a fogyasztó között interperszonális kapcsolatról tudjunk beszélni. Ezek a kritériumok a következők:

- kölcsönösség, mely szerint a partnerek kölcsönösen hatást gyakorolnak egymásra

- célszerüség, a kapcsolat valamilyen valós és konkrét cél érdekében jön létre,

- a kapcsolat komplexitása, az előnyök sokoldalúságát jelenti a résztvevők számára,

- folytonosság, vagyis folyamatos interakciót jelent a résztvevők között.

A fentiek alapján megállapítható, hogy amennyiben a fogyasztó úgy tekint a márkára mint egy emberre, akkor beszélhetünk a fogyasztó és a márka közötti viszonyról és ez a viszony hasonlóságokat mutat az interperszonális kapcsolatokkal. Fournier (1998) a márka antropomorfizálására alapozta vizsgálatait, és egy feltáró kutatás eredményeként a márka és a fogyasztó közötti viszony 15 típusát különítette el. A fogyasztó és a márka közötti viszony nem csak márkakedvelésből és -rajongásból állhat, hanem gyakran negatív viszonyulás és ellenszenv is kialakulhat egy-egy márkával szemben. A témánkból adódóan nekünk elsősorban a márkákhoz való pozitív viszonyulás a releváns, de fontosnak tartjuk leszögezni, hogy a fogyasztó és a márka közötti viszony nem csak pozitív elöjelü lehet. A következőkben néhány példával szemléltetve bemutatjuk azokat a pozitív kapcsolattípusokat, amelyek a primer kutatásunk szempontjából relevánsak. Az egyes kapcsolattípusoknál említett példák egyfajta iránymutatásként szolgálnak - az egyes kapcsolattípusba sorolt termékkategóriák egyénenként eltérőek lehetnek, illetve ettől eltérő termékkategóriák is megjelenhetnek.

1. Laza haveri kapcsolat, amely alacsony bizalmat és elköteleződést jelent, nincsenek elvárások kölcsönösségre és haszon szerzésére. Eseti jellegü kapcsolatra utal. A márkaválasztás szintjén ez többnyire úgy jelenik meg, hogy a fogyasztó azokat a márkákat, amelyekhez laza haveri viszony füzi, gyakran váltogatja, mivel kevésbé kötődik hozzá. Különböző napi fogyasztási cikkeknél, jellemzően élelmiszereknél figyelhető meg ez a kapcsolattípus.

2. Legjobb barát, amely az önkéntes szövetség és a kölcsönösség alapelvére épít. A kapcsolatot a folyamatos pozitív jutalmazás tartja fenn. A márka imázsa és a fogyasztó énképe illeszkednek egymáshoz. A fogyasztó olyan márkát választ, ami hozzá segíti őt ahhoz, hogy kifejezze a személyiségét. Jellemzően ruházati cikkeknél, parfümöknél, karórák esetében fordul elö.

3. Elkötelezett partnerkapcsolat, amely a hosszú távú, önként választott, a társadalom által támogatott kapcsolatokat foglalja magában. Bizalom, szeretet, hüség és elkötelezettség jellemzi, a kedvezőtlen körülmények ellenére is igyekszik a fogyasztó fenntartani a kapcsolatot a márkával, például áremelkedés után is megvásárolja a terméket. Jellemzően autómárkáknál és telefonmárkáknál figyelhető meg. Ezeket a termékeket a fogyasztó nem havonta vásárolja, és az idő folyamán kialakult nagyfokú bizalom miatt egy későbbi vásárlás alkalmával, nagy valószínűséggel újra fogja vásárolni a bevált márkát.

4. Udvarlás, amely átmeneti állapotot jelent, amikor egy új terméket próbál ki a fogyasztó. Tulajdonképpen minden olyan márka ide sorolható, amellyel a fogyasztó az ,ismerkedés” fázisában van, de jellemzően kozmetikumok és müszaki cikkek jelennek meg ebben a kategóriában. Az udvarlás az elkötelezett kapcsolatot előzi meg.

5. A gyermekkori barát korábbi kapcsolatokból eredő kötődés, amely múltbeli emlékekhez füződik. Többnyire kényelem- és biztonságérzet miatt választjuk. Jellemzően csokoládé és üdítőitalok tartoznak ide, amelyekről tudjuk, hogy finomak, így ezek megvásárlásával nem kockáztatunk.

6. A függőség, egy erősen emocionális kapcsolat, melynek alapját az az érzés adja, hogy a márka nem helyettesíthető. A márka minőségbeli ingadozását gyakran tolerálja a fogyasztó. Különösen megfigyelhető ez a kapcsolattípus szolgáltatások, illetve okostelefonok körében. 
A fogyasztó és a márka közötti viszonyok ilyen szofisztikált megközelítését az indokolja, hogy bár minden fenti esetben érzelmi kötődésröl és lojalitásról beszélhetünk, mégis vannak érzékelhető különbségek a viszonyokban, amelyek befolyásolhatják a fogyasztói attitüdöt, illetve a viszonyhoz illeszkedő kommunikációs stratégiát.

A fogyasztó és a márka közötti kapcsolattípusokat nemcsak típusonként, hanem mélységében is vizsgálhatjuk. Erre a célra Fournier (1998) az elöző elmélet kiterjesztett adaptációját a márkaviszony-minőség elméletet (brand relationship quality) alkotta meg, amely a fogyasztó és a márka közötti kapcsolat erősségének és mélységének mérése szolgáló modell. A szerző szerint márka és az egyén közötti viszony minőségét hat tényező határozza meg. A szeretet és a szenvedély mértéke (1), amely a fogyasztó érzelmeinek összességét jelenti a kedvelt márkával kapcsolatban. A márka fogyasztóval való kapcsolatának erőssége (2) arra utal, hogy az egyén életstílusához kapcsolódik-e a márka, valamint a márka mennyire része a fogyasztó énképének. A függőség mértéke (3) arra vonatkozik, hogy a márka mennyire vált a fogyasztó mindennapi életének a részévé, és mennyire tudná helyettesíteni azt. A kitartás (4) szintje azt mutatja meg, hogy mennyire tart ki a kedvelt márkája mellett az egyén, a márka iránti elkötelezettség mértékét mutatja meg. A bizalom (5) mértéke, amely azt jelzi, hogy az egyén mennyire bízik a márkában. Az utolsó elem a partnerség minősége (6), amely arra utal, hogy az egyén a márkát mennyire tartja korrekt partnernek, ugyanis a fogyasztó számára fontos, hogy partnerként kezeljék és törődjenek vele. Ebben az esetben a márka és a vállalat összemosódik a márkaviszony-minőség értékelése során (Fournier, 1998). Az imént bemutatott tényezőket az 2. ábra szemlélteti.

\section{A márkaviszony-minőség hat tényezője}

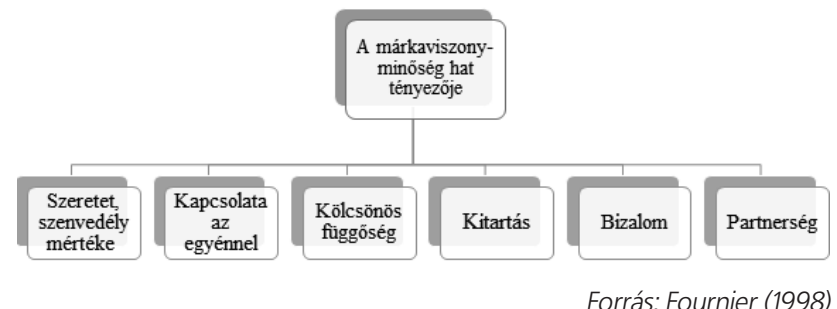

A szakirodalmi áttekintésből látható, hogy a fogyasztó és a márka közötti viszony igen változatos formákban jelenhet meg, és - bár Fournier (1998) tipizálása széles körben elterjedt - ebböl adódóan hiányzik az általánosan elfogadott elméleti keretrendszer. Mindezt figyelembe véve meglátásunk szerint érdemes feltáró vizsgálatokat végezni a fent bemutatott viszonyok beazonosítására és jellemzésére magyar fogyasztók körében.

\section{A primer kutatás módszertana}

Kutatásunk tágabb értelemben vett célja, hogy hazai viszonyok között feltárjuk, létezik-e érzelmi kötődés a már- ka iránt. Szükebb értelemben vett célunk, hogy feltárjuk a fogyasztó és az általa kedvelt márka közötti viszony sajátosságait, továbbá az érzelmi kötődés - amennyiben kimutatható -, miként jelenik meg a viselkedés, az attitüd és a vélemény szintjén. Ennek érdekében fókuszcsoportos kutatást végeztünk egy szükebb - de a világon leggyakrabban kutatott (Rapp - Hill, 2015) - célcsoport, az egyetemisták körében.

A márkaszeretet és a márkaviszony témaköre egy erösen érzelemvezérelt terület, így elsősorban mélyreható, feltáró jellegű vizsgálatot igényel. Nem véletlen, hogy a téma meghatározó kutatói (Aaker, 1997; Fournier, 1998; Aggarwal, 2004) szintén a kvalitatív módszert alkalmazták. A kvalitatív kutatási módszerek közül a fókuszcsoportos megkérdezést választottuk, hiszen ez a módszer lehetőséget teremt arra, hogy a kutatási kérdéseinket fókuszáltan tudjuk vizsgálni, továbbá a fókuszcsoportban résztvevők az adott kérdéskörben ki tudják fejezni saját véleményeiket, érzéseiket és gondolataikat (Veres - Hoffmann - Kozák, 2009). Mindezeken túl egy komplexebb képet kaphatunk általa az adott kérdéskört vizsgálva, illetve az eredmények kiindulási alapot adhatnak egy későbbi kvantitatív kutatáshoz. A választásunk azért esett az egyetemista fiatalokra, mert fogyasztásukra és vásárlói magatartásukra jellemző a sokszínüség (Noble et al., 2009), ez a célcsoport fogékonyabb az újdonságokra (Kovács, 2009; Törőcsik, 2010; Kazár, 2015) és a többségük már rendelkezik önálló keresettel. Ebben az életszakaszban az önmegvalósítás, a saját identitás felépítése fontos szerepet játszik, mely befolyásolja márkaválasztásukat is (Prónay, 2011; Málovics et al., 2015).

Kutatásunkban a Szegedi Tudományegyetem Gazdaságtudományi Kar alap- és mesterszakos hallgatóinak körében négy fókuszcsoportos megkérdezést folytattunk le. A fókuszcsoportos megkérdezések lebonyolítására 2016 őszén került sor, melyekről hangfelvétel készült. A kutatás során a szerzők felváltva töltötték be a moderátor, illetve a megfigyelő és az adminisztráló szerepét. Az adminisztráció során a föbb megállapításokat elektronikus úton rögzítettük, ezzel elösegítve az elhangzottak későbbi feldolgozását. Az elemzés során a két kutató egymástól függetlenül elemezte az összes interjút, majd az eredmények összevetése, iterálása után alakult ki a konszenzusos eredmény.

A kutatásban résztvevők nemek szerinti megoszlását tekintve a nők nagyobb arányt képviseltek, mint a férfiak. A nők száma 25 fö, míg a férfiak száma 9 fö volt. A résztvevők kiválasztása önkényes módon történt, a téma iránt érdeklődő hallgatók önkéntes jelentkezése által. A megkérdezés első nagyobb blokkjában a vizsgálati alanyoknak egy lapra fel kellett írniuk egy általuk kedvelt márkát (és a termékkategóriát, amelyben az megjelenik), amelyhez ragaszkodnak, amit nem szívesen cserélnének le egy másik márkára. Továbbá egy érzést is kellett írniuk a márkával kapcsolatban, amit a termék megvásárlásakor vagy használata során éreznek. Fontosnak tartottuk, hogy úgy nyilatkozzanak a megkérdezettek a kedvelt márkákról a kutatás első fázisában, hogy a márkanevet nem említik, csak a termékkategóriát, amelyben a márka megjelenik. A 
márkanévre csak a fókuszcsoportos megkérdezés későbbi fázisában derült fény. A fókuszcsoportos megkérdezés következő blokkjában felsoroltuk a Fournier-féle (1998) fogyasztó-márka közötti kapcsolattípusokból azt a hat típust, amelyeket korábban a szakirodalmi kitekintés során bemutattunk, továbbá ismertettük az interjúalanyoknak az egyes kapcsolattípusok jellemzőit. A megkérdezetteknek minden kapcsolattípushoz írniuk kellett egy-egy márkát, melyhez az adott viszony füzi őket. A szakirodalomból ismert kapcsolattípusokból a laza haveri kapcsolatot, a legjobb barát, az elkötelezett partnerkapcsolat, az udvarlás, a gyermekkori barát és a függőséget vizsgáltuk. Az első blokkban választott márkát be lehetett sorolni e kapcsolattípusok valamelyikébe is. A fókuszcsoportos megkérdezés e fázisában már meg lehetett nevezni a márkanevet. A célunk az volt, hogy megvizsgáljuk az alanyok miként képesek márkákat társítani ezekhez az érzésekhez.

\section{A primer kutatás eredményei}

A következőkben megvizsgáljuk fókuszcsoportos kutatásunk eredményeit. Az elemzést 7 fó megállapítás szerint mutatjuk be, amelyek mentén megragadható a márkákhoz való kötődés érzelmi oldala, illetve a fogyasztó és a márka közötti viszony. A fejezet végén egy ábrán összegezzük a meghatározó gondolatokat.

M1 megállapitás: A résztvevők képesek érzelmileg kötödni a márkákhoz, ez az érzelem leginkább az önmegnyugtatáshoz áll közel.

A válaszokban kedvelt márka fogyasztása mögött a márka önkifejező jellege is megjelent, hangsúlyosabban azonban a márka használatát inkább a fogyasztás önmegnyugtató jellege támasztotta alá a megkérdezettek körében. A fiatalok arról nyilatkoztak, hogy azért fontos számukra ez a márka, mert hozzásegíti öket az önmegvalósításhoz, valamint a márka használata megnyugvást jelent számukra.

\section{„Kreativitásomat segíti megvalósítani. Eszköz és társ is az életemben. Szabadságérzést kelt bennem. Csak személyes élmény van a márkával kapcsolatban, az én személyes ötleteimet valósítom meg az eszköz segítségével." (Brigi, 22)}

„Bizalom és megnyugvás, amit a márka jelent számomra. Mindig lesz valami, amihez nyúlhatok, ha valamilyen kérdésem lesz." (Blanka, 20)

Továbbá megfigyelhető volt az is, hogy a szeretett márka jelentése kiemelkedik, megváltozik a fiatalok számára.

"Lehet, hogy van jobb, de számunkra ez la mi márkánk] már érzelmi kötődést is okoz, így már nem csak egy termék, hanem „A" termék, ami számunkra nem csak azt jelenti, ami, hanem már többletjelentéssel is bír."(Jázmin, 19)

„Hozzám nőtt, segíti a munkámat." (Brigi, 22)
A márkához való érzelmi kötődés kapcsán vizsgáltuk azt is, hogy milyen érzései lennének, illetve mit tennének a megkérdezettek abban az esetben, ha az általuk kedvelt márka abban a termékkategóriában megszünne. A csalódottság érzése, a szomorúság és a tehetetlenség érzése egy-két kivételtől eltekintve szinte mindenkinél felmerült.

\section{"A gépet beraknám a szekrénybe, emlékbe, vigyáz- nék rá." (Brigi, 22)}

„Igazi ürességet éreznék." (Dóri, 22)

\section{„Világvége hangulatom lenne." (Béla, 22)}

A fenti megállapítások által arra a következtetésre jutottunk, hogy a fiatalok kiemelt jelentőséget tulajdonítanak a kedvelt márkájuknak, saját maguk részeként tekintenek rá. A válaszok jól szemléltetik a tárgyakhoz, illetve a márkákhoz való kötődés érzelmi oldalát. A márka elvesztése érzelmi reakciókat váltana ki belőlük, csalódottság az üresség és a hiány érzését.

M2 megállapitás: A szeretett márkához kapcsolódó pozitív élmények és - különösen az elsö - tapasztalatok hozzájárulnak a márkához való érzelmi kötödés kialakulásához.

Kutatási eredményeinkből megállapítható, hogy a vizsgált alanyok esetében személyes élmény köthető a kedvelt márkához. Többségében ezek az élmények az első használathoz kapcsolódnak. Ezek az élmények meghatározóak a későbbi márkaválasztás és a lojalitás szempontjából.

„Jóérzéssel töltött el, hogy ezért a termékért én küzdöttem meg, és hogy én teremtettem meg a pénzt, ez egy felnőtt érzést adott nekem." (Brigi, 22)

"Az elsőt ajándékba kaptam, de annyira megszerettem, hogy utána még vettem magamnak egyet." (Anna, 20)

„Apám egyszer átment rajta targoncával, és utána is müködött. És ez ugyanaz a telefon volt, ami beleesett egyszer a tóba, és azóta is müködik." (Ramóna, 21)

„Szerbiából származom, és amikor átjöttem ide, akkor ez volt az első termék, amit kipróbáltam, és rögtön ráfüggtem." (Tiana, 19)

A fenti megállapítások összegzéseként elmondható, hogy a kedvelt márkákhoz kapcsolódó érzelmek korábbi élményekből (is) fakadnak, melyek hozzájárultak a szorosabb kötődés kialakulásához.

M3 megállapitás: A kedvelt márka kapcsán az érzelmek képesek felülírni a racionalitást.

A megkérdezettek válaszai alapján az a következtetés vonható le, hogy egyrészt véleményük szerint nem - vagy nem feltétlenül - a legjobb ár-érték arányú a kedvelt márkájuk, mégis kitartanak mellette. Másrészt megállapítható, hogy az érzelmi kötődés képes felülírni a racionális 
érveket. A fiatalok tudják, hogy nem az általuk használt márka a legjobb márka, mégsem térnének át egy jobb márkához ugyanilyen áron, mert ezt „árulásnak”, a „hűség megvásárlásának" éreznék.

"Biztos, hogy ennél a márkánál van jobb, de az se kellene ugyanilyen áron, ezt ilyen elárulás érzésnek érezném. Egy idő után már nem az számít, hogy mennyibe kerül ez a dolog, amit szeretünk, hanem az, hogy ezt a dolgot szeretjük és pont. Nyilván van egy felső lélektani határ, de akkor is az a lényeg, hogy ezt szeretjük, és ezt kifizetjük." (Sándor, 24)

„Nem engedném megvásárolni a hüségemet, mert azt érezném, hogyha egy másik márka olcsóbban nyújtaná ugyanezt, hogy meg akarják vásárolni a hüségemet." (Dóri, 22)

\section{"Az ár-érték arány túlzás, de mégsem cserélném le." (Brigi, 24)}

A fenti vélemények is jól alátámasztják a márkaválasztás érzelmi oldalának relevanciáját, melyben az az érdekes, hogy az érzelmeknek nem csak a racionális érveket erősítő, hanem akár azokat felülíró hatását is sikerült kimutatni. Megállapítható, hogy az érzelmi elköteleződés miatt sokkal magasabban van a lélektani határ a váltásra késztető árkülönbözetben, mint azt más fogyasztók racionálisnak tartanák.

M4 megállapítás: Megvédik a kedvelt márkát az ellenvéleményekkel szemben.

A fókuszcsoportos kutatásban részt vett fiatalok körében is kirajzolódott a szakirodalomból már jól ismert márkavédés jelensége. Bizonyos esetben a saját személyük elleni támadásnak vették a márkát érő negatív kritikát.

\section{„Magunkra vesszük, ha azt a márkát leszólják, amit szeretünk, akkor az olyan, mintha ránk mondanánk valami rosszat." (Rita, 20)}

„Ha az ember valamit szeret, és azt más leszólja, akkor azt igazságtalannak érzi a márkával szemben, persze lehet, hogy csak az ismeretek hiánya miatt mondja ezt a másik, de azért reflexszerüen védem." (Brigi,22)

A fenti vélemények jól illusztrálják a gyakorlatban a márkavédés jelenségét, mely egy érzelmeken alapuló reakció a márka védelmének érdekében. A márkakötődés érzelmi oldalát ez is alátámaszthatja.

M5 megállapítás: A megkérdezettek képesek a márkák antropomorfizálására, azonban nem feltétlenül magukhoz hasonlónak képzelik el.

A márka antropomorfizálása és a márka személyiségével való azonosulás vizsgálata érdekes, és némileg ellentmondó eredményeket hozott. A megkérdezettek énképéhez többnyire illeszkedik a kedvelt márka személyisége, tudnak vele azonosulni. Többen azonban nem olyan személynek tudták elképzelni az általuk kedvelt márkát, mint amilyenek ők maguk, sőt annyira nem, hogy gyakran el- lentétes nemünek, idősebbnek vagy sokkal fiatalabbnak képzelték el a márkát személyként. Többen nem is tudtak azonosulni a márka személyiségével, de ettől függetlenül kedvelik és akár vonzónak is találják a márka személyiségét. Megjelent továbbá a márkaszemélyiség alakulásának jelensége, azaz dinamizmusa, ami egyfajta újrapozicionálásként értelmezhető. Ennek a változásnak az eredménye azonban nem feltétlenül pozitív a fogyasztók számára.

„Régen 40-es üzletembernek tudtam volna elképzelni, de ma már 15 és 25 év közötti lány, aki a social mediaban él. Régen tudtam volna vele azonosulni, de ma már nem. Ez a lány állandóan fényképezi magát, aztán megszerkeszti és megír róla egy posztot, nyomkodja a telefonját, tökéletes képet akar mutatni magáról. Nem szimpatikus ez a viselkedés." (Brigi, 24)

„Habár a motort férfiak használják, maga a márka inkább nőként jelenik meg. A férfiak általában nőnek nevezik a motorjukat. 25-30 éves sportos átlagos, érettebb gondolkodású szeretni való nő lenne." ( Péter, 22)

„Fiatal 3-4 éves kisfiúnak képzelem el, aki sokat labdázik. Egy homokozóban tudom elképzelni egy csokival a kezében." (Vanessa, 19)

„Japán mester lenne, 50-60 év körüli férfi, aki tiszteletet érdemel, akitöl tanulhatsz." (Timi, 18)

M6 megállapitás: A megkérdezettek tudják értelmezni a márkák szintjén az egyes kapcsolattipusokat.

1. táblázat

Az egyes kapcsolattípusoknál említett márkanevek
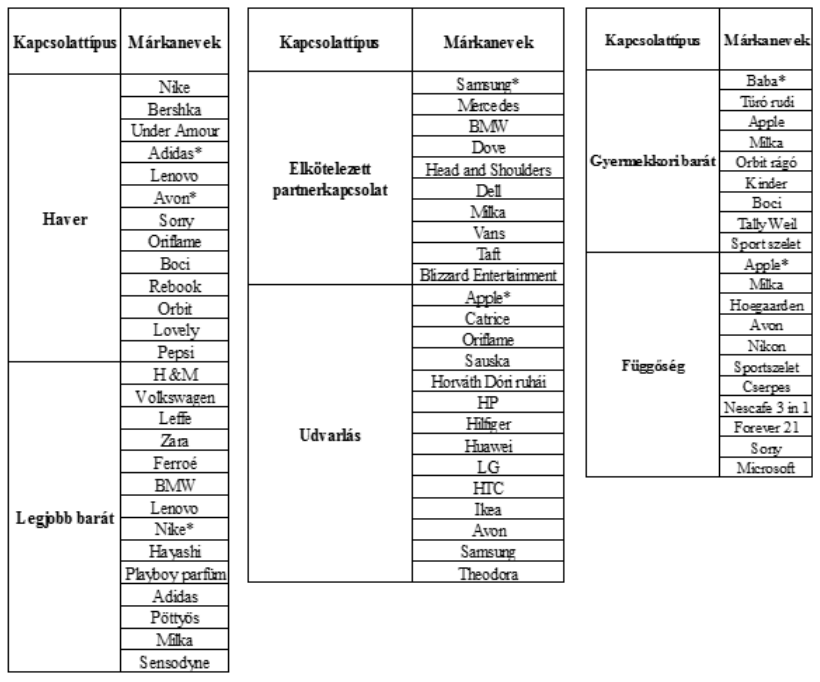

Forrás: Primer kutatás alapján saját szerkesztés

Az általunk felsorolt kapcsolattípusok mindegyikéhez egy-két kivételtől eltekintve a megkérdezettek megjelöltek egy-egy márkát. A „haver” kapcsolattípusnál sportruházati cikkeket és kozmetikumokat említettek (Adidas, 
Avon). A „legjobb barát” kapcsolattípusnál jellemzően sportruházati cikket neveztek meg (Nike). Az „,elkötelezett partnerkapcsolat" viszonynál túlnyomó többségében müszaki cikkeket említettek a megkérdezettek (Samsung). A ,gyermekkori barát" viszonynál a fiatalok jelentős része kozmetikai terméket említett (Baba). Érdekes eredményt hozott a „függőség” és az ,udvarlás” kapcsolattípushoz írt márkanevek gyakorisága. Mindkét típusnál az Apple volt az a márka, amit a legtöbben említettek. Az egyes kapcsolattípusoknál említett márkákat az 1. táblázat mutatja. A táblázatban a csillaggal jelölt márkaneveket több interjúalany is megnevezte az adott kapcsolattípusnál.

M7 megállapitás: A megkérdezettek a szeretett márkájukhoz füzödö viszonynak jellemzöen a laza haveri vagy a szorosabb baráti kapcsolatot nevezték meg.

A megkérdezettek említettek olyan kapcsolattípusokat is, amelyek az általunk felsoroltak között nem szerepeltek, de többségében a laza haveri vagy a szoros baráti kapcsolatként írták le a szeretett márkájukkal való kapcsolatukat.

\section{"Szorosabb baráti kapcsolat lenne. Ö tanítana en- gem infóból." (Miklós, 22)}

\section{"Lazább baráti kapcsolat lenne a márkával." (Melitta,} 24)

"Szorosabb baráti viszony lenne a márkával. Ha beszélni tudna a márka, sokat tudna rólam." (Ági, 18)

„Nagynéniként tudnom elképzelni a márkát. Ido"sebb lenne nálam, de nem annyira, nem egy alá-fölé rendeltségi viszony lenne, mint egy szülö-gyerek viszonynál, hanem egy lazább társ lenne, akihez tudok fordulni az életben és közelebb van hozzám korban." (Barbi, 21)

\section{„Munkahelyi ismerős lenne." (Viktor, 19)}

3. ábra

\section{A márkához való érzelmi kötődés sokszínűsége}

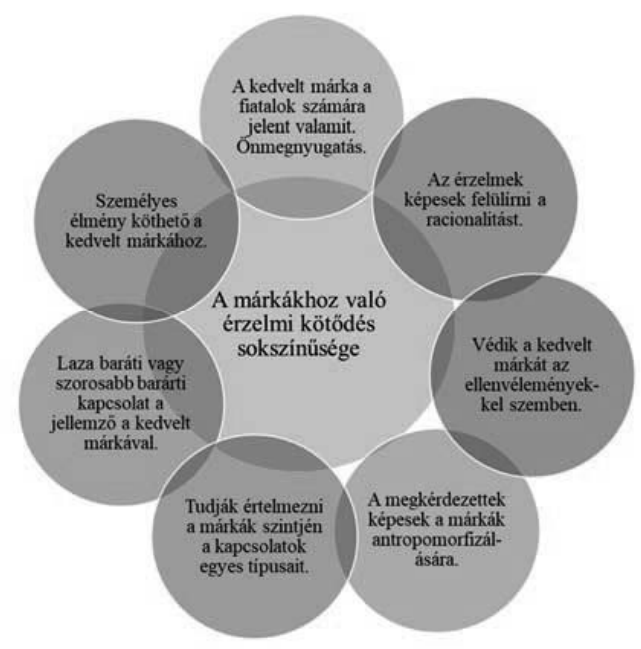

Forrás: Primer kutatás alapján saját szerkesztés
A fenti megállapítások vegyes képet mutatnak a márka megszemélyesítésénél és a márkával való azonosulásban. Habár általános tapasztalat, hogy szívesen alakítanának ki lazább haveri vagy szorosabb baráti kapcsolatot a kedvelt márkájukkal, ha az ember lenne, de abban már megosztottak voltak a válaszadók, hogy a márka személyként hozzájuk hasonló lenne-e.

A bemutatott eredményeket a 3. ábrán összegezzük.

\section{Összefoglalás}

Összességében kijelenthetjük, hogy a márkákhoz való érzelmi kötődés kimutatható az általunk megkérdezettek körében, noha ezek az érzelmek nagyon vegyesek, összetettek és különböző indíttatásúak lehetnek. Ezek alapján úgy véljük, a márkaszeretet jelenségét nem lehet általánosítani, fontosnak tartjuk leszögezni, hogy létezik ez a jelenség, befolyással bír a lojalitásra, de nem tartjuk szerencsésnek egyfajta általánosító megközelítést alkalmazni e jelenségre, és egyszerüen szeretetmárkának (lovemarks) nevezni minden olyan márkát, mellyel kapcsolatban pozitív érzelmek (is) kimutathatóak. Sokkal célszerübb az érzelmi oldal sokszínüségét hangsúlyozni. A fókuszcsoportos kutatásunk eredményei a márkákkal kapcsolatos érzelmek változatosságát igazolják, bár ezek a megállapítások pusztán az általunk vizsgált - igen szűk és speciális - mintára érvényesek. Eredményeink korlátozottan engednek betekintést nyújtani a fogyasztó-márka kapcsolat területére, de az eredményekből jól látszódik, hogy a fiatalok képesek érzelmileg is kötődni a márkákhoz és ez az érzelem leginkább az önmegnyugtatáshoz áll közel. Az eredményeink azt mutatják, hogy a szimbolikus fogyasztás ezeknél a márkáknál inkább belső, mint külső szimbolizmust jelent, mert énképükhöz nem mindig illeszkedik a márka, még akár teljesen más is a márka személyisége, de szívesen kialakítanának vele vele laza haveri vagy szorosabb baráti viszonyt, vagyis a kötődés fontosabb, mint az önkifejezés ezeknél a márkáknál. Ez az eredményünk összhangban van Fournier (1998) azon megállapításával, miszerint a márkák által nyújtott előnyök - amelyek lehetnek szimbolikus, érzelmi vagy pusztán funkcionális előnyök -, azok a tényezők, amelyek miatt a márkának nagy jelentősége van azok számára, akik használják. Továbbá ez az érzelmi kötődés képes lehet felülírni a racionális gondolkodást abban az értelemben, hogy elismerik ugyan, hogy van az általuk kedvelt márkánál jobb márka, de ha lehetőség nyílna rá, ugyanazon az áron sem vásárolnák meg a jobb márkát, hủek maradnának a kedvelt márkájukhoz. Fontos megjegyezni, hogy ez a jelenség némileg különbözik a lojalitást kvázi definíciószerüen jellemző alacsonyabb márkaváltási hajlandóságtól. Itt ugyanis a hüség nem racionális alapon nyugszik, azaz nem pusztán az elégedettségből vagy a magasabb észlelt minőségből fakad, hanem abból az érzésből, hogy nem akarja „elárulni” a márkát a fogyasztó. Továbbá az eredményeinkből az is jól látszódik, amelyre Fournier (1998) a tanulmányában szintén rávilágított, hogy a márkakapcsolatok, a fogyasztók által megélt márkatapasztalatok és a márkával kapcsolatos élmények szintjén értelmezhetőek. Ennek értelmében a fogyasztó márkához való viszonyát alakítja és formálja az a tény, hogy milyen tapasztalatai és élményei vannak a márkával kapcso- 
latban. Eredményeink azt mutatják, hogy az első személyes tapasztalatok különösen fontos szerepet töltenek be a márkához való érzelmi kötődés kialakulásában.

Müködőképes elméletnek bizonyult az emberi kapcsolatok mintájára alapozott fogyasztó és a márka közötti érzelmi kötődés kutatása, és a márkaviszony-elmélet adaptálása fókuszcsoportjaink során, hiszen nem okozott problémát az interjúalanyoknak, hogy az egyes márkákhoz meghatározott viszonyokat társítsanak, illetve fordítva. Továbbá az sem okozott problémát, hogy úgy nyilatkozzanak egy általuk kedvelt márkáról, mintha az egy személy lenne. Fournier-féle (1998) féle kapcsolattípusok mellett a kutatásban résztvevők új márkaviszony-típusokat is megneveztek, amelyek a munkatársi viszonyhoz és a rokoni kapcsolatokhoz voltak hasonlóak. Mindezeken túl összhangban Albert - Merunka (2013) és Batra et al. (2012) eredményeivel, mi is azt a következtetést tudjuk levonni, hogy a szeretet létező jelenség a fogyasztás, illetve a fogyasztó-márka kapcsolat területén. Ezek alapján úgy véljük a primer kutatásunk eredményei kellően alátámasztják, hogy van létjogosultsága a márkához való érzelmi kötődés, illetve a fogyasztó-márka közötti érzelmi kapcsolat mélyebb vizsgálatának hazánkban is.

Véleményünk szerint a vállalatoknak érdemes lehet ,közelebb vinni" a márkákat a fogyasztókhoz, nagyobb teret adva az érzelmek kialakulásának márka és fogyasztója között, ugyanis a márkaszeretet pozitívan befolyásolja a márka iránti elköteleződést. Az említett ,közelebb vitel” gyakorlati szempontból a személyes találkozóktól a márka köré épített élményvilágon át, a storytelling technikákig számos módszerrel elősegíthető. A márkamenedzserek számára fontos megállapítás lehet továbbá, hogy a „legjobb minőség” hangsúlyozása mellett - vagy akár helyette - a „megbízhatóság”, a „stabilitás”, az ,én megszokott márkám” érzés kommunikálása hasznosabb lehet annak érdekében, hogy elősegítsék vagy elmélyítsék a fogyasztók márka iránti érzelmi kötődését. Érdemes továbbá kiemelni, hogy ha nem különösebben foglalkoznak az érzelmi kötődés kialakításával márkájukhoz kapcsolódóan, akkor is létrejöhet ez a kapcsolat, csak nem feltétlenül a cég által kívánt formában - sőt akár éppen a cég érdekeivel ellentétes módon is alakulhat. A márkaszeretet kutatásával kapcsolatban számos kérdés nyitva áll még, de ennek ellenére a márkához való érzelmi kötődés vizsgálatának megállapításaink szerint van relevanciája, így reményeink szerint további hazai kutatásokat inspirálhat ez a téma.

\section{Felhasznált irodalom}

Aaker, J. L. (1997): Dimension of Brand Personality. Journal of Marketing Research, 34, p. 347-356.

Aggarwal, P. (2004): The Effects of Brand Relationship Norma on Consumer Attitudes and Behavior. Journal of Consumer Research, 31- June, p. 87-101.

Albert, N. - Merunka, D. (2013): The Role of Brand Love in Consumer-Brand Relationships. Journal of Consumer Marketing, 30/3, p. 258-266.

Bandyopadhyay, S. - Martell, M. (2007): Does Attitudional Loyalty Influence Behavioral Loyalty? A Theoretical and Empirical Study. Journal of Retailing and Consumer Services, 14, May, p. 35-44.
Batra, R. - Ahuvia, A. - Bagozzi, P. R. (2012): Brand Love. Journal of Marketing Research, 76, p. 1-16.

Belk, R. W. (1988): Possessions and the Extended Self. Journal of Consumer Research, 15- September, p. 139-168.

Fournier, S. (1998): Consumers and Their Brands: Developing Relationship Theory in Consumer Research. Journal of Consumer Research, 24, p. 343-372.

Grzeskowiak, S. - Sirgy, J. M. (2007) : Consumer Well-Being (CWB): The Effects of Self-Image Congruence, Brand Community Belongingness, Brand Loyalty, and Consumption Recency. Applied Research Quality Life, 2 (4), p. 289-304.

Gyulavári T. - Malota E. (2014): Az énkép-illeszkedés elmélet szerepe a fogyasztók turisztikai desztinációértékelésében. Marketing \& Management, 48 (3), p. 5-14.

Kazár K. (2015): Lojalitást meghatározó tényezők feltárása zenei fesztiválok esetén fókuszálva a márka szerepére. Marketing \& Menedzsment, 49 (3), p. 36-49.

Kovács K. (2009): A divatterjedés és a divattermékek fogyasztását befolyásoló tényezők empirikus vizsgálata a hazai fiatalok körében. Marketing \& Menedzsment, 43 (1), p. 62-71.

Kressman, F. - Sirgy, M. J. - Herrmann, A. - Huber, F. - Huber, S. - Lee, D. J. (2006): Direct and Indirect Effects of Self-Image Congruence on Brand Loyalty. Journal of Business Research, 59 (8), p. 955-964.

Levy, S. J. (1959): Symbols for Sale. Harvard Business Review, 37 (4), p. 117-124.

Málovics É. - Prónay Sz. - Kincsesné V. B. (2015): Az "Erasmusnemzedék" útra kel - Y generációs egyetemisták külföldi utazási motivációinak és szokásainak feltárása. Marketing \& Menedzsment, 49 (1), p. 43-57.

Noble, S. M. - Haytko, D. L. - Phillips, J. (2009): What Drives College-age Generation Y Consumers? Journal of Business Research, 62 (6), p. $617-628$.

Oliver, R. L. (1999): Whence Consumer Loyalty? Journal of Marketing, 63, p. 33-44.

Prónay Sz. (2011): Fiatalok fogyasztásának vizsgálata: szegmentáció. Marketing \& Menedzsment, 45-március, p. 26-37.

Rapp, J. M. - Hill, R. P. (2015): Lordy, Lordy, Look Who's 40! The Journal of Consumer Research Reaches a Milestone. Journal of Consumer Research, 42 (1), p. 19-29.Roberts, K. (2004): Jövő a márkák után - Lovemarks. Budapest: Magyar Könyvklub

Sirgy, M. J. (1982): Self-Concept in Consumer Behavior: A Critical Review. Journal of Consumer Research, 9, p. 287-301.

Smith, A. (1759/1975): The Theory of Moral Sentiments. Revised edition. Reprinted Raphael, D. D. - Macfie, A. L. Oxford: Clarendon Press

Töröcsik M. (2000): Empatikus marketing. Budapest: Bagolyvár Könyvkiadó

Törőcsik M. (2009): Vásárlói magatartás. Ember az élmény és a feladat között. Budapest: Akadémiai Kiadó

Törőcsik M. (2010): A fiatalok fogyasztói magatartása - az egyetemek fö célcsoportjának megértése. In: Töröcsik M. - Kuráth G. (ed): Egyetemi marketing, marketing a felsőoktatásban. Pécs: Pécsi Tudományegyetem, p. 123-141.

Uncles, M. D.- Dowling, G. R.- Hammond, K. (2003): Customer Loyalty and Customer Loyalty Programs. Journal of Consumer Marketing, 20 (4), p. 294-316.

Veblen, T. (1925/2006): Conspicuous Consumption. Reprinted from The Theory of the Leisure Class, New York: Penguin Group 